\title{
Influence of Nutrient Limitation and Growth Rate on the Outer Membrane Proteins of Klebsiella aerogenes NCTC 418
}

\author{
By AART STERKENBURG, * ELLY VLEGELS AND JAN T. M. WOUTERS \\ Laboratorium voor Microbiologie, Universiteit van Amsterdam, Nieuwe Achtergracht 127, \\ 1018 WS Amsterdam, The Netherlands
}

(Received 2 December 1983; revised 21 March 1984)

\begin{abstract}
Four major proteins with molecular weights of $78000,37000,34000$ and 20000 were present in the envelope of Klebsiella aerogenes when cultured at a high specific growth rate. However, at lower growth rates, the protein content and composition of the envelope depended on the imposed nutrient limitation. Under potassium-, carbon-, sulphur- and phosphorus-limited conditions, derepression of synthesis of limitation-specific proteins was observed, their apparent molecular weights being $90000,48000,41000$ and 36000 , respectively. Nitrogenlimited cells had no additional proteins. For a particular limiting nutrient, expression of the limitation-specific proteins was independent of the chemical or physical form in which the nutrient was supplied. Under potassium or sulphur limitation the specific proteins were present maximally at the lowest imposed growth rate, whereas under carbon limitation a maximum expression of these proteins was found at moderate growth rates. It is concluded that limitationspecific proteins which are associated with the outer membrane function in the uptake of limiting nutrients or, possibly, limitation-releasing compounds.
\end{abstract}

\section{INTRODUCTION}

The outer membrane of Gram-negative bacteria separates the growth environment from the periplasmic space and forms a selective barrier for permeation of solutes. This is accomplished by a class of trans-membrane proteins, called porins, that form aqueous pores through which nutrients may pass (DiRienzo et al., 1978; Nikaido \& Nakae, 1979). In Escherichia coli, Salmonella typhimurium and Pseudomonas aeruginosa, outer-membrane proteins (OMPs) form non-specific channels through the outer membrane, selecting only on size and hydrophilicity the molecule that can be transported (Nikaido et al., 1980; Nakae, 1976; Hancock et al., 1979). Other OMPs are involved in a more specific uptake of nucleosides (Hantke, 1976), amino acids (Heuzenroeder \& Reeves, 1981) and vitamin $\mathbf{B}_{12}$ (DiMasi et al., 1973), whereas permeation of maltose and maltodextrines in E. coli preferably occurs through the MalB protein (Szmelcman \& Hofnung, 1976; Nakae \& Ishii, 1980). Furthermore, a number of proteins are related to the uptake of chelated iron in E. coli (Hancock et al., 1976) and in Vibrio cholerae (Sigel \& Payne, 1982). When growth was restricted by the supply of the phosphorus source, expression of the PhoE protein was observed in E. coli (Argast \& Boos, 1980; Overbeeke \& Lugtenberg, 1980) and of protein $P$ in $P$. aeruginosa (Hancock et al., 1982). Both proteins appeared to form channels through the outer membrane with affinity for phosphorus-containing compounds and anionic solutes (Hancock et al., 1982; Overbeeke \& Lugtenberg, 1982; Nikaido et al., 1983). Physiologically, this was a remarkable observation, since the substrate that was actually growthlimiting could be adequately transported through the general aqueous pores present in the outer membane of both species (Nikaido et al., 1980; Hancock et al., 1979; Benz \& Hancock, 1981).

Abbreviation: OMP, outer-membrane protein. 
In this study we investigated whether synthesis of limitation-specific OMPs is a more general phenomenon. In addition, we were interested in the effect of growth rate on the expression of the OMPs. In order to obtain steady-state nutrient-limited growth, we used continuous cultures of Klebsiella aerogenes. This species was chosen because a pronounced phenotypic response with respect to the functioning of uptake systems located within the cytoplasmic membrane had already been demonstrated in this organism (Tempest et al., 1970; Neijssel et al., 1975; Sterkenburg \& Wouters, 1981). Furthermore, earlier studies of Robinson \& Tempest (1973) demonstrated that this organism can easily alter the protein composition of its cell envelope as a response to growth conditions.

\section{METHODS}

Organism. Klebsiella aerogenes NCTC 418 was maintained by monthly subculture on nutrient agar.

Growth conditions. Organisms were grown aerobically in a $300 \mathrm{ml}$ chemostat (Bioflo, New Brunswick Scientific). Media were based on the following compositions: $5 \mathrm{~mm}-\mathrm{NaH}_{2} \mathrm{PO}_{4}, 50 \mathrm{~mm}-\mathrm{NH}_{4} \mathrm{Cl}, 5 \mathrm{~mm}-\mathrm{KCl}, 1 \mathrm{~mm}-$ $\mathrm{Na}_{2} \mathrm{SO}_{4}, 1 \mathrm{~mm}$-citric acid, $0.63 \mathrm{mM}-\mathrm{MgCl}_{2}, 0.01 \mathrm{~mm}-\mathrm{CaCl}_{2}, 1.5 \%(\mathrm{w} / \mathrm{v})$ glucose and trace elements as described by Evans et al. (1970). In carbon-limited media, the amount of the carbon source (glucose, glycerol or maltose) was lowered to $0.1 \%(\mathrm{w} / \mathrm{v})$; phosphorus-limited media contained $0.2 \mathrm{mM}-\mathrm{NaH}_{2} \mathrm{PO}_{4}$ or $0.2 \mathrm{mM}-s n$-glycerol 3 phosphate; for nitrogen limitation $3 \mathrm{mM}-\mathrm{NH}_{4} \mathrm{Cl}$ (or $3 \mathrm{~mm}-\mathrm{NaNO}_{3}$, or 3-mM-sodium glutamate) was present in the medium and $47 \mathrm{~mm}-\mathrm{NaCl}$ was added for adjustment of medium osmolarity; sulphur limitation was obtained with $0.04 \mathrm{mM}-\mathrm{Na}_{2} \mathrm{SO}_{4}$ or $0.04 \mathrm{mM}-$ methionine, and potassium limitation with $0.04 \mathrm{mM}-\mathrm{KCl}$ in the medium. Growth temperature was $37^{\circ} \mathrm{C}$; the culture $\mathrm{pH}$ was monitored in situ and was automatically maintained at 6.8 by addition of $1 \mathrm{M}-\mathrm{NaOH}$ (phosphorus limitation) or $4 \mathrm{M}-\mathrm{NaOH}$ (other limitations). Samples were withdrawn when the culture had reached a steady state. In batch culture, organisms were grown in Nutrient Broth (Difco) at $37^{\circ} \mathrm{C}$ under vigorous aeration.

Isolation of cell encelopes. Culture samples ( $50 \mathrm{ml}$, containing approximately $20 \mathrm{mg}$ dry weight of bacteria) were washed with $0.9 \%(w / v) ~ N a C l$; cells were resuspended in $10 \mathrm{ml}$ buffer containing $50 \mathrm{~mm}$ - Tris/ $\mathrm{HCl}$ and $2 \mathrm{mM}$ EDTA (pH 8.5) and subjected to ultrasound ( $80 \mathrm{~W}$; Sonifier, Branson Instruments, Danbury, Conn., USA) for periods of $15 \mathrm{~s}$ with cooling intervals on ice. A cell-free extract was obtained by centrifugation at $1000 \mathrm{~g}$ for $20 \mathrm{~min}$ $\left(4{ }^{\circ} \mathrm{C}\right)$ in a Sorvall RC2-B centrifuge and crude envelopes were collected from the resulting supernatant by subsequent centrifugation $\left(12000 \mathrm{~g}, 1 \mathrm{~h}, 4^{\circ} \mathrm{C}\right)$ and resuspended in $2 \mathrm{~mm}$-Tris/ $\mathrm{HCl}$ buffer, $\mathrm{pH} 7 \cdot 8$, to a final concentration of 3-10 mg protein $\mathrm{ml}^{-1}$.

Extraction of encelope proteins. Envelopes were washed twice with $2 \mathrm{~mm}-\mathrm{Tris} / \mathrm{HCl}, \mathrm{pH} 7 \cdot 8$, and resuspended in $10 \mathrm{~mm}$-HEPES, pH 7.4, containing $2 \%(\mathrm{w} / \mathrm{v})$ Triton X-100 (Schnaitman, 1971). After $15 \mathrm{~min}$ at room temperature, samples were cooled on ice, and the insoluble fraction was collected by centrifugation $(49000 \mathrm{~g}, 1 \mathrm{~h}$, $4{ }^{\circ} \mathrm{C}$ ) and resuspended in $2 \mathrm{mM}$ - Tris/ $\mathrm{HCl}, \mathrm{pH} 7 \cdot 8$, to a final concentration of $40 \mathrm{mg}^{2}$ protein $\mathrm{ml}^{-1}$.

Equilibrium sucrose density gradient centrifugation. Crude envelopes (approximately $20 \mathrm{mg}$ protein in $0.5 \mathrm{ml}$ ) were layered on top of a discontinuous $35-55 \%(\mathrm{w} / \mathrm{w})$ sucrose gradient in $10 \mathrm{~mm}$-HEPES, $\mathrm{pH} 7.4(5 \%$ concentration intervals) and centrifuged for $48 \mathrm{~h}$ at $131000 \mathrm{~g}\left(4^{\circ} \mathrm{C}\right)$ in a MSE Super Speed 75 ultracentrifuge. The gradient was fractionated into $0.5 \mathrm{ml}$ samples with continuous recording of $A_{260}$ (Uvicord, LKB). Samples were diluted fivefold with $10 \mathrm{mM}$-HEPES, $\mathrm{pH} 7 \cdot 4$, concentrated by centrifugation at $49000 \mathrm{~g}\left(2 \mathrm{~h}, 4^{\circ} \mathrm{C}\right)$ and resuspended in $2 \mathrm{mM}$-Tris/ $\mathrm{HCl}, \mathrm{pH} 7 \cdot 8$.

SDS-polyacrylamide gel electrophoresis. This was performed as described by Lugtenberg et al. (1975). Crude envelopes were boiled for $5 \mathrm{~min}$ in gel sample buffer and samples were applied to a $11 \%(\mathrm{w} / \mathrm{v})$ polyacrylamide gel. Gels were run at $30 \mathrm{~mA}$ constant current. Protein bands were stained with an aqueous solution of $0.04 \%(\mathrm{w} / \mathrm{v})$ Coomassie Blue G250 containing 25\%(v/v) 2-propanol and 7\%(v/v) acetic acid and destained in a $12 \cdot 5 \%(\mathrm{v} / \mathrm{v}) 2-$ propanol $/ 7 \%(\mathrm{v} / \mathrm{v})$ acetic acid mixture. Molecular weights were determined from relative mobilities when compared with high-molecular weight protein standards (Bio-Rad).

Densitometric analysis of gels. To obtain quantitative densitometric data, three different amounts of total envelope proteins were applied to the gels (approximately 10, 20 and $40 \mu \mathrm{g}$ protein). Protein patterns were analysed by densitometric tracing (densitometer model DD2, Kipp \& Zonen, Delft, The Netherlands) and the peaks were integrated (model 602 Minigrator, Spectra Physics, Santa Clara, Calif, USA). Integration values obtained from the three samples of each envelope preparation were compared, and for each individual OMP band a correction was made to allow for differing saturation kinetics of staining. Corrected integration values were correlated with values found for three standard amounts $(2 \cdot 5,5$ and $10 \mu \mathrm{g}$, respectively) of bovine serum albumin, that had also been applied to each gel. Intensities of OMP bands were converted to equivalents of the albumin standard and then expressed as percentages of the total number of OMP albumin-equivalents present in a sample.

Chemicals. SDS ( $90 \%$ pure) was from Merck; SDS (95\% pure) was from Sigma, a $1: 1(\mathrm{w} / \mathrm{w})$ mixture was used; bovine serum albumin and Coomassie blue G250 were from Sigma. All other reagents were analytical grade. 


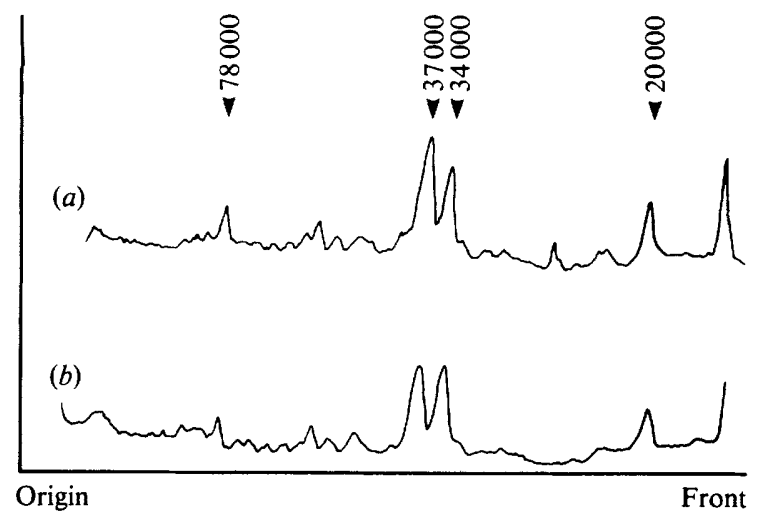

Fig. 1. Densitometric tracings of the membrane protein pattern of batch-grown $K$. aerogenes. Organisms were cultured in nutrient broth and samples were withdrawn from the early exponential phase $(a)$ and the stationary phase $(b)$. Proteins of crude envelopes from these samples were separated by SDS polyacrylamide gel electrophoresis and stained with Coomassie Blue G250. The obtained protein pattern was analysed by densitometry. Apparent molecular weights of the major peaks are indicated.

\section{RESULTS}

\section{Envelope proteins in batch culture}

In batch culture, growth occurs at an optimal rate until it becomes restricted, and subsequently stopped, by exhaustion of some nutrient(s) or accumulation of excreted products. We examined the effect on the envelope proteins of the large differences in growth conditions between the early exponential phase and the stationary phase. The cell envelope contained four major proteins with apparent molecular weights of $78000(78 \mathrm{kDal}), 37 \mathrm{kDal}, 34 \mathrm{kDal}$ and $20 \mathrm{kDal}$. The protein composition was not markedly dependent on the growth phase from which cells had been harvested. Only minor differences in relative amounts of the $34 \mathrm{kDal}$ and the $37 \mathrm{kDal}$ proteins could be detected (Fig. $1 a, b$ ). Treatment of envelope samples with Triton X100 yielded an insoluble fraction that was enriched with these major proteins.

\section{OMPs in continuous culture}

Effect of nutrient limitation on the OMPs. In the chemostat, the protein composition of the cell envelopes depended on the imposed growth conditions. Under nitrogen-limited conditions the protein profile was similar to the pattern found in batch culture (Fig. $2 a, d$ ). The $44 \mathrm{kDal}$ protein that appeared in these samples presumably was mainly situated in the cytoplasmic membrane, since in sucrose density gradients only a small amount of this protein was found in the outer membrane fraction (Fig. $3 b$ ). This protein was solubilized by treatment of the envelopes with Triton X-100. The protein profile was independent of the nature of the nitrogen source because it was found not only under ammonia limitation, but also under nitrate- and glutamate-limited conditions. When phosphorus (inorganic phosphate as well as $s n$-glycerol 3-phosphate) was the growth-limiting nutrient, the $37 \mathrm{kDal}$ protein was present to a much lesser extent. Instead, a protein that moved slightly faster was found with an apparent molecular weight of $36 \mathrm{kDal}$ (Fig. 2b). Under sulphur (sulphate, methionine) limitation the 34 and $37 \mathrm{kDal}$ proteins were present, and relatively high amounts of a $41 \mathrm{kDal}$ protein were found (Fig. $2 d$ ). Glucose-limited cultures had a membrane protein profile that was rather comparable with the pattern found under nitrogen limitation; however, in these cultures large amounts of a $48 \mathrm{kDal}$ protein were detected (Fig. $2 f$ ). This protein was also present in comparable amounts in the envelopes of glycerol- or maltose-limited cultures.

In the high molecular weight range, significant alterations in the protein pattern were found under potassium limitation. Under these conditions a protein band with apparent molecular 


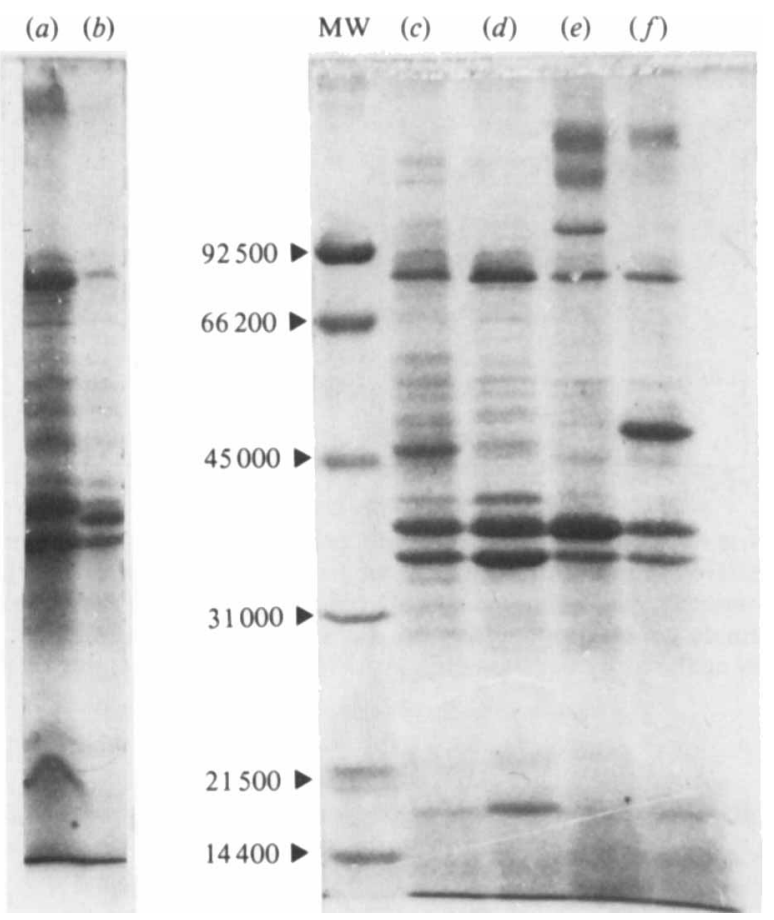

Fig. 2. Membrane proteins from chemostat cultures of $K$. aerogenes, grown under $(a, c)$ ammonia-, $(b)$ phosphate-, $(d)$ sulphur-, $(e)$ potassium- and $(f)$ glucose-limitation. Molecular weights of proteins in the reference standard (MW) are indicated.

weight of $90 \mathrm{kDal}$ was present to a much higher extent (Fig. $2 e$ ) than in cultures grown with excess of potassium.

Crude envelopes from chemostat-grown cells were subjected to sucrose density gradient centrifugation. Samples separated into two fractions (Fig. $3 a$ ), with the major proteins being associated for the most part with the high-density membrane fraction (Fig. $3 b$ ). Envelope samples from glucose-limited cultures were also treated with Triton X-100. The major proteins shown in Fig. 2( $f$ ) were recovered in the insoluble fraction (Fig. 4). Similar experiments were done on envelopes from phosphate-, sulphate- and potassium-limited cells, and these demonstrated that the $36 \mathrm{kDal}, 41 \mathrm{kDal}$ and $90 \mathrm{kDal}$ proteins, respectively, were also Triton $\mathrm{X}$ 100 -insoluble (data not shown). Thus, this procedure gave an insoluble fraction enriched with the proteins that were associated with the high-density fraction obtained after sucrose density centrifugation of the envelopes (see Fig. 3). It was therefore concluded that the additional limitation-specific, Triton X-100-insoluble proteins present in the crude envelope preparations were mainly located within, or closely associated with the outer membrane.

Effect of growth rate on the OMPs. The phenotypic variability of the OMP pattern shown in Fig. 2 was found in cultures with a low growth rate; that is, with an extremely low extracellular concentration of the growth-limiting nutrient. In order to study the relationship between this concentration and the OMP profile, the effect of the culture dilution rate on the protein composition of the other membrane was investigated.

In Fig. 5 the relationship between the intensity of the OMP bands and the growth rate is shown for potassium-limited cultures. At low growth rates the expression of the $90 \mathrm{kDal}$ protein was very pronounced. The amount of this protein decreased with increasing growth rates and was present in only small amounts at a culture dilution rate of $0.7 \mathrm{~h}^{-1}$.

To measure the relative amounts of OMPs, the output of the densitometric analysis was integrated. In Fig. 6 relative amounts of OMPs are expressed as percentages of the total amount 

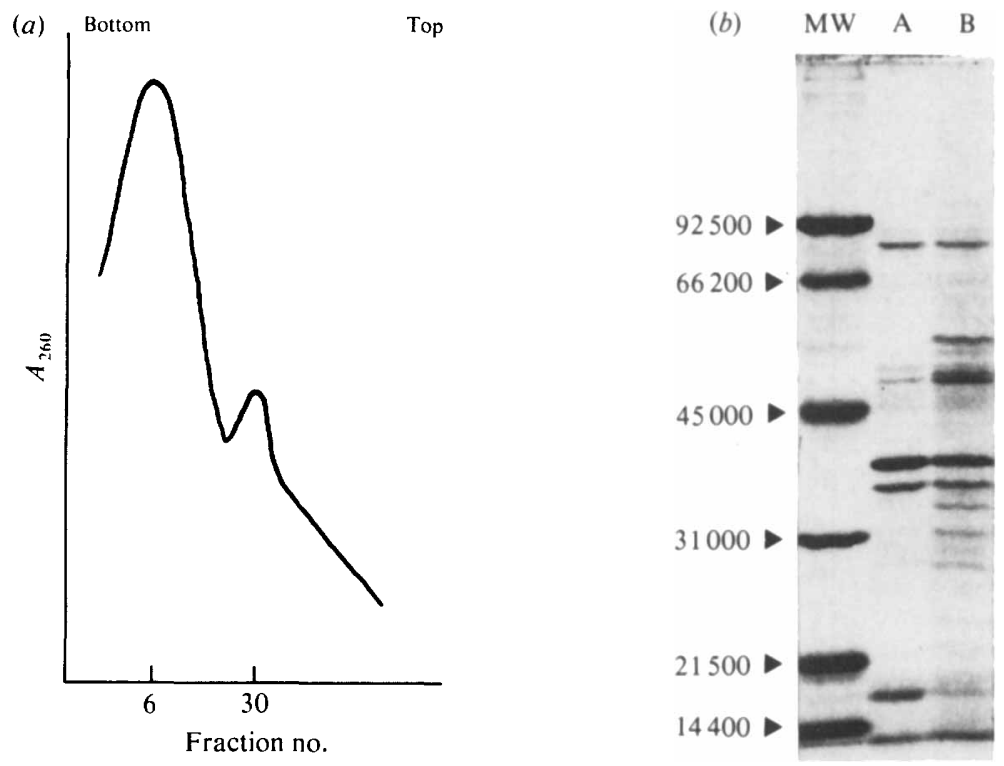

Fig. 3. Sucrose density centrifugation of crude envelopes from cells grown under nitrogen limitation at a growth rate of $0 \cdot 2 \mathrm{~h}^{-1}$. Envelopes were centrifuged on a discontinuous sucrose gradient, and eluted as described in Methods. (a) Elution of the gradient as recorded by its absorbance (in arbitrary units) at $260 \mathrm{~nm}$; (b) SDS polyacrylamide gel electrophoresis of samples $(200 \mu \mathrm{g}$ protein) from the fractions 6 (lane A) and 30 (lane B), respectively. MW, molecular weight standard.

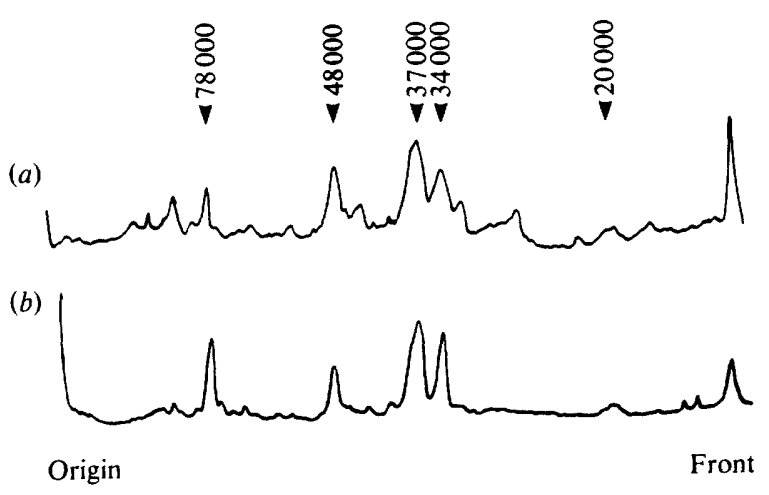

Fig. 4. Extraction of proteins from crude envelopes of cells, grown under glucose limitation at a growth rate of $0.2 \mathrm{~h}^{-1}$. Membrane samples were resuspended in buffer containing Triton X-100, left for $15 \mathrm{~min}$ at room temperature, and the insoluble fraction was collected by centrifugation. Proteins from crude envelopes $(a)$ and the Triton X-100-insoluble fraction $(b)$ were separated by SDS-polyacrylamide gel electrophoresis, stained and the protein pattern obtained analysed by densitometry.

of OMPs. Generally, the amount of limitation-specific OMPs decreased with increasing growth rates. Under potassium limitation (Fig. $6 a$ ) the $90 \mathrm{kDal}$ protein amounted to $48 \%$ of the total OMP at a low culture dilution rate $\left(0.1 \mathrm{~h}^{-1}\right)$ and was barely detectable at a growth rate as high as $0.7 \mathrm{~h}^{-1}$. Likewise, under sulphur limitation (Fig. $6 c$ ) the highest amount of the $41 \mathrm{kDal}$ protein $(18 \%)$ was found at a low growth rate $\left(0 \cdot 2 \mathrm{~h}^{-1}\right)$ and its amount also decreased gradually at higher growth rates. This protein was still present in small amounts at a very high dilution rate $\left(1 \cdot 2 \mathrm{~h}^{-1}\right)$, which was near to the maximum specific growth rate of $K$. aerogenes under the imposed chemostat conditions. The amount of $48 \mathrm{kDal}$ protein present under carbon limitation 


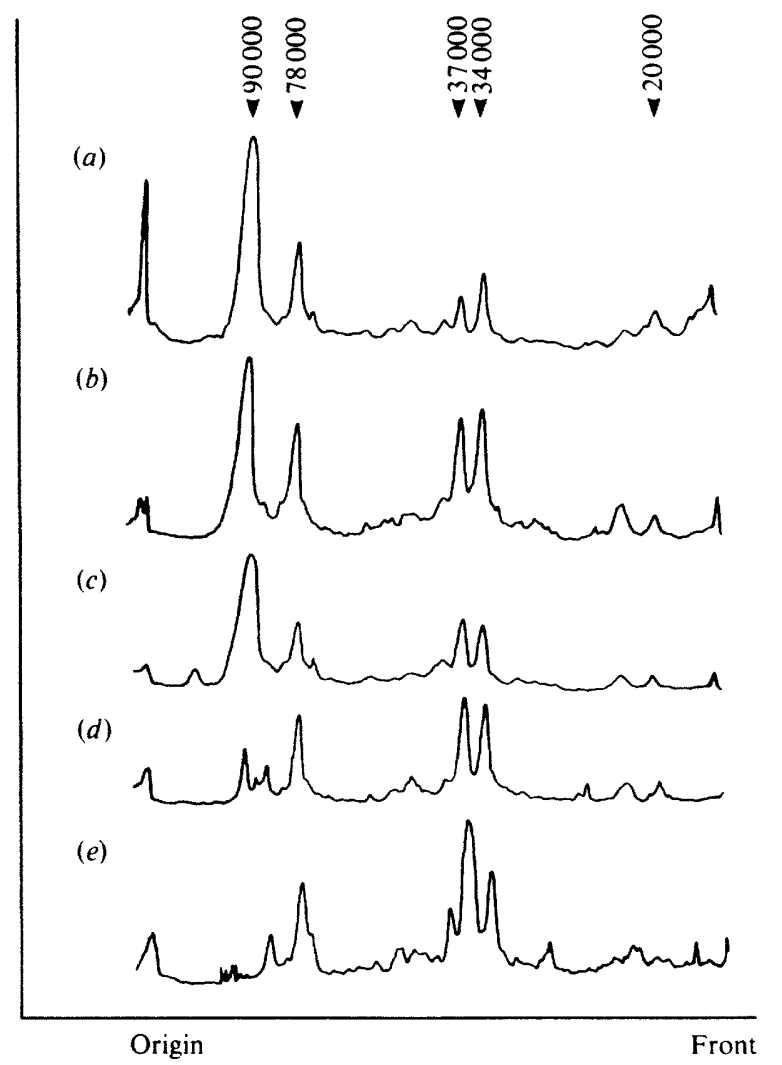

Fig. 5. Effect of growth rate on the protein composition of membranes from potassium-limited cultures. Samples were withdrawn from steady state cultures with growth rate $0 \cdot 1 \mathrm{~h}^{-1}(a), 0.4 \mathrm{~h}^{-1}(b)$, $0.5 \mathrm{~h}^{-1}(c), 0.6 \mathrm{~h}^{-1}(d)$ and $0.7 \mathrm{~h}^{-1}(e)$. Further experimental procedures were as described in the legend to Fig. 1 .

(Fig. $6 \mathrm{~b}$ ) was maximal (34\%) at a dilution rate of $0.3 \mathrm{~h}^{-1}$, and decreased to barely detectable levels at a higher growth rate $\left(1 \cdot 1 \mathrm{~h}^{-1}\right)$.

\section{DISCUSSION}

Differences in protein localization within the cell envelope may result in differences in the extent of solubilization of individual proteins upon treatment of membrane samples with detergents. Both Triton X-100 and Sarkosyl NL-50 have been used extensively for the isolation of the OMPs (Schnaitman, 1971) and penicillin-binding proteins (Spratt, 1977) in E. coli. Differential solubility in Triton X-100 has been used as a basis for the isolation of the outer membrane and purification of OMPs in Pseudomonas (Hancock \& Carey, 1980; Hancock et al., 1982), Proteus and Klebsiella (Hofstra \& Dankert, 1979; Hofstra et al., 1980). In the Klebsiella strain studied in this paper, proteins associated with the outer membrane were selectively retained in the envelope fraction after treatment with Triton X-100 (Figs 1 and 2).

The OMP profile of early exponential phase batch cultures in nutrient broth was comparable with the pattern found in chemostat cultures with a high growth rate. In stationary phase cells, no additional OMP was detected, suggesting that growth may have been halted by nitrogen starvation. However, it is possible that the changes in growth conditions between the late exponential and the stationary phases may have occurred over too short a period, thereby not allowing the culture enough time for its cells to adapt.

Differences in the protein composition of the outer membrane affected by alterations in 


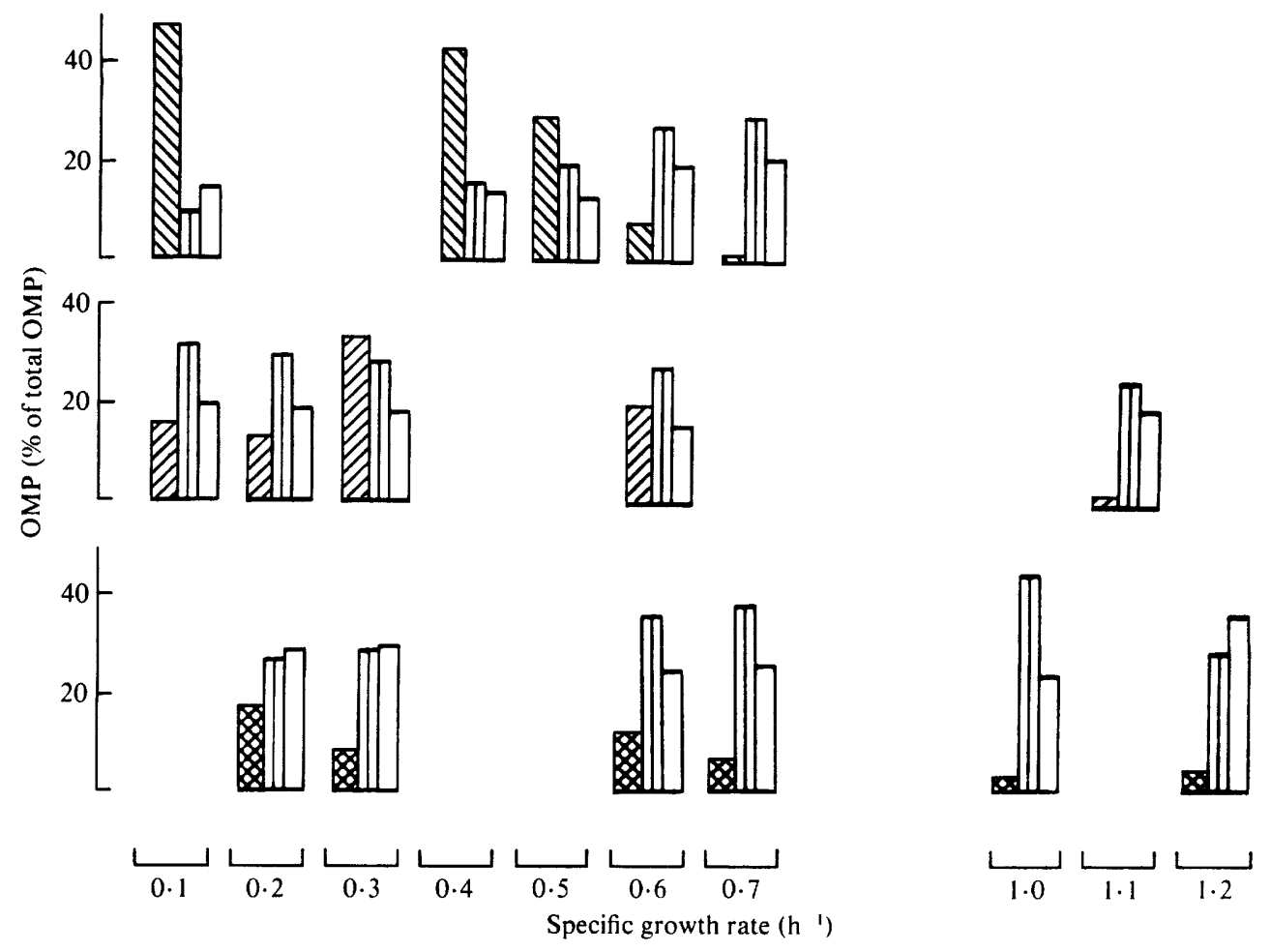

(a)

(b)

(c)

Fig. 6. Relationship between growth rate and relative intensity of the major OMPs of $K$. aerogenes, grown under $(a)$ potassium-, $(b)$ carbon- and $(c)$ sulphur-limitation. Electrophoretic patterns were analysed by densitometry and integration of the peaks obtained. Intensities of the $90000(\square), 48000(\square)$,

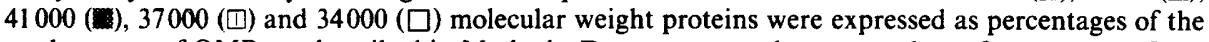
total amount of OMPs as described in Methods. Data represent the mean values of components from traces of at least three different samples from at least two different chemostat runs. Individual values varied at most by $20 \%$ of the mean value.

growth conditions may give an indication of the function of the OMPs. The synthesis of the $36 \mathrm{kDal}$ protein was specifically derepressed under phosphorus limitation, and this was also found for the PhoE protein in E. coli (Overbeeke \& Lugtenberg, 1980) and protein $\mathrm{P}$ in $P$. aeruginosa (Hancock et al., 1982). It is conceivable that the $36 \mathrm{kDal}$ protein is functionally related to the PhoE pore protein, enabling phosphorus-containing compounds to penetrate the outer membrane efficiently. Similarly, the $48 \mathrm{kDal}$ protein found under carbon limitation, and the $41 \mathrm{kDal}$ protein found under sulphur limitation, might function in an efficient uptake of carbon- or sulphur-containing compounds, respectively. The protein composition of the cell envelope under nitrogen limitation indicates that under these conditions the outer membrane provides the means of uptake of nitrogen-containing compounds without an additional protein. Indeed, the relatively high amounts of the $44 \mathrm{kDal}$ Triton X-100-soluble protein indicate that nitrogen-limited conditions rather affect the composition of the cytoplasmic membrane. The $48 \mathrm{kDal}$ protein found under carbon limitation may be functionally related to the MalB protein in $E$. coli that forms pores for maltose and maltodextrins (Szmelcman \& Hofnung, 1976; Nakae \& Ishii, 1980). The appearance of the limitation-specific OMPs was not influenced by the nature of the growth-limiting nutrient (organic; negatively or positively charged inorganic). Presumably these proteins do not form specific pores for the substrate actually present in limiting amounts but rather function in optimizing of the uptake of limitation-releasing compounds.

The $90 \mathrm{kDal}$ protein was maximally expressed under potassium limitation at a low growth rate. Under these conditions the potassium gradient across the cell envelope is extremely large 
(Hueting et al., 1979; Tempest et al., 1966) and the $90 \mathrm{kDal}$ protein may serve to impede leakage of $\mathrm{K}^{+}$ions from the cell. The affinity of the PhoE and the MalB proteins in E. coli for their substrates has been related to the presence of a recognition site on the protein (Overbeeke \& Lugtenberg, 1982; Ferenci et al., 1980). By analogy, if the $90 \mathrm{kDal}$ protein has an affinity for $\mathrm{K}^{+}$ ions and, hence, $\mathrm{K}^{+}$-binding capacity, leakage of the ion from the cell would be reduced, thus making a contribution towards the maintenance of the $\mathrm{K}^{+}$gradient across the cytoplasmic membrane.

Limitation-specific OMPs were barely detectable at high growth rates. Under these conditions the extracellular concentration of the limiting nutrient is relatively high and, therefore, the cultural phenotypic response was less pronounced. In the case of potassium- or sulphurlimited growth, the limitation-specific OMPs were maximally present at the lowest imposed cultural dilution rate. Under carbon limitation, however, the maximum amount of limitationspecific OMPs was not found at the lowest growth rate. Presumably it was not only the imposed nutrient limitation that determined the composition of the outer membrane, but also the rate at which nutrients must cross the membrane in order to replenish the periplasmic concentration of nutrients required for the maintenance of the growth rate. Under carbon-limited conditions the initial rise in the amount of the limitation-specific OMP which accompanied increases in growth rates may have reflected this necessity of an increased flux of nutrients across the membrane.

\section{REFERENCES}

Argast, M. \& Boos, W. (1980). Co-regulation in Escherichia coli of a novel transport system for $s n$ glycerol-3-phosphate and outer membrane protein Ic (e, E) with alkaline phosphatase and phosphatebinding protein. Journal of Bacteriology 143, 142150

Benz, R. \& Hancock, R. E. W. (1981). Properties of the large ion permeable pores formed from protein $F$ of Pseudomonas aeruginosa in lipid bilayer membranes. Biochimica et biophysica acta 646, 298-308.

DiMasi, D. R., White, S. C., Schnaitman, C. A. \& BRADBEER, C. (1973). Transport of vitamin B12 in Escherichia coli: common receptor sites for vitamin B 12 and the E colicins on the outer membrane of the cell envelope. Journal of Bacteriology 115, 506513

DiRienzo, J. M., Nakamura, K. \& Inouye, M. (1978). The outer membrane proteins of Gram-negative bacteria: biosynthesis, assembly and functions. Annual Review of Biochemistry 47, 481-532.

Evans, C. G. T., Herbert, D. \& Tempest, D. W. (1970). The continuous cultivation of microorganisms. 2. Construction of a chemostat. Methods in Microbiology 2, 277-327.

Ferenci, T., Schwentorat, M., Ullrich, S. \& VILMART, J. (1980). Lambda receptor in the outer membrane of Escherichia coli as a binding protein for maltodextrines and starch polysaccharides. Journal of Bacteriology 142, 521-526.

Hancock, R. E. W. \& Carey, A. M. (1980). Protein D1 - a glucose-inducible, pore-forming protein from the outer membrane of Pseudomonas aeruginosa. FEMS Microbiology Letters 8, 105-109.

HaNCOCK, R. E. W., HANTKe, K. \& Braun, V. (1976). Iron transport in Escherichia coli $\mathrm{K}-12$ : involvement of the colicin $\mathrm{B}$ receptor and of a citrate-inducible protein. Journal of Bacteriology 127, 1370-1375.

Hancock, R. E. W., Decad, G. M. \& Nikaido, H. (1979). Identification of the protein producing transmembrane diffusion pores in the outer membrane of
Pseudomonas aeruginosa PAO1. Biochimica et biophysica acta 554, 323-331.

Hancock, R. E. W., PoOle, K. \& Benz, R. (1982). Outer membrane protein P of Pseudomonas aerugin$o s a$ : regulation by phosphate deficiency and formation of small anion-specific channels in lipid bilayer membranes. Journal of Bacteriology 150, 730-738.

HANTKE, K. (1976). Phage T6-colicin K receptor and nucleoside transport in Escherichia coli. FEBS Letters 70, 109-112.

Heuzenroeder, M. W. \& Reeves, P. (1981). The $t s . x$ protein of Escherichia coli can act as a pore for amino acids. Journal of Bacteriology 147, 1113-1116.

Hofstra, H. \& DankerT, J. (1979). Antigenic crossreactivity of major outer membrane proteins in Enterobacteriaceae species. Journal of General Microbiology' 111, 293-302.

Hofstra, H., VAN Tol, M. J. D. \& Dankert, J. (1980). Cross-reactivity of major outer membrane proteins of Enterobacteriaceae, studied by crossed immunoelectrophoresis. Journal of Bacteriology 143, 328-337.

Hueting, S., De Lange, T. \& Tempest, D. W. (1979). Energy requirement of maintenance of the transmembrane potassium gradient in Klebsiella aerogenes NCTC 418: A continuous culture study. Archices of Microbiology 123, 183-188.

Lugtenberg, B., Meijers, J., Peters, R., Van der HoEk, P. \& VAN Alphen, L. (1975). Electrophoretic resolution of the major outer membrane protein of Escherichia coli $\mathrm{K} 12$ into four bands. FEBS Letters 58, 254-258.

NAKAE, T. (1976). Outer membrane of Salmonella. Isolation of a protein complex that produces transmembrane channels. Journal of Biological Chemistry 251, 2176-2178.

NAKAE, T. \& IsHII, J. (1980). Permeability properties of Escherichia coli outer membrane containing poreforming proteins: comparison between lambda receptor protein and porin for saccharide permeation. Journal of Bacteriology 142, 735-740. 
Neijssel, O. M., Hueting, S., Crabbendam, K. J. \& TEMPEST, D. W. (1975). Dual pathways of glycerol assimilation in Klebsiella aerogenes NCIB 418. Their regulation and possible functional significance. Archives of Microbiology 104, 83-87.

NikaIDO, H. \& NAKaE, T. (1979). The outer membrane of Gram-negative bacteria. Advances in Microbial Physiology 20, 163-250.

Nikaido, H., LuCKey, M. \& RosenberG, E. Y. (1980). Nonspecific and specific diffusion channels in the outer membrane of Escherichia coli. Journal of Supramolecular Structure 13, 305-313.

Nikaido, H., RosenberG, E. Y. \& Foulds, J. (1983). Porin channels in Escherichia coli: Studies with betalactams in intact cells. Journal of Bacteriology 153, 232-240.

OverbeEke, N. \& LUGTENBerg, B. (1980). Expression of outer membrane protein e (PhoE protein) of Escherichia coli $\mathrm{K} 12$ by phosphate limitation. FEBS Letters 112, 229-232.

OVERBEEKE, N. \& LugtenberG, B. (1982). Recognition site for phosphorus-containing compounds and other negatively charged solutes on the PhoE protein pore of the outer membrane of Escherichia coli K12. European Journal of Biochemistry 26, 113-118.

Robinson, A. \& Tempest, D. W. (1973). Phenotypic variability of the envelope proteins of Klebsiella aerogenes. Journal of General Microbiology 78, 361370 .
Schnaitman, C. A. (1971). Solubilization of the cytoplasmic membrane of Escherichia coli by Triton X100. Journal of Bacteriology 108, 545-552.

Sigel, S. P. \& PAYNe, S. M. (1982). Effect of iron limitation on growth, siderophore production, and expression of outer membrane proteins of Vibrio cholerae. Journal of Bacteriology 150, 148-155.

SpratT, B. G. (1977). Properties of the penicillinbinding proteins of Escherichia coli K-12. European Journal of Biochemistry 72, 341-352.

SterkenburG, A. \& Wouters, J. T. M. (1981). Phenotypic variability of the sensitivity to cycloserine of Klebsiella aerogenes NCTC 418, growing in chemostat culture. Journal of General Microbiology 124, 29-34.

Szmelcman, S. \& Hofnung, M. (1976). Maltose transport in Escherichia coli K12: Involvement of the bacteriophage lambda receptor. Journal of Bacteriology 124, 112-118.

Tempest, D. W., Dicks, J. W. \& Hunter, J. R. (1966). The interrelationship between potassium, magnesium and phosphorus in potassium-limited chemostat cultures of Aerobacter aerogenes. Journal of General Microbiology 45, 135-146.

Tempest, D. W., Meers, J. L. \& Brown, C. M. (1970). Synthesis of glutamate in Aerobacter aerogenes by a hitherto unknown route. Biochemical Journal 117, 405-407. 